\title{
Article \\ Cyprus and Sardinia at the Transition from the Bronze to the Iron Age: A Sacred Landscape Approach
}

\author{
Giorgos Papantoniou ${ }^{1, *(\mathbb{C})}$ and Anna Depalmas ${ }^{2}$ (i) \\ 1 Department of Classics, Trinity College Dublin, D02 PN40 Dublin, Ireland \\ 2 Department of Humanities and Social Sciences, University of Sassari, 07100 Sassari, Italy; depalmas@uniss.it \\ * Correspondence: papantg@tcd.ie
}

check for updates

Citation: Papantoniou, Giorgos, and Anna Depalmas. 2022. Cyprus and Sardinia at the Transition from the Bronze to the Iron Age: A Sacred Landscape Approach. Religions 13: 48. https://doi.org/10.3390/ rel13010048

Academic Editor: Sabine Hyland

Received: 24 October 2021

Accepted: 19 December 2021

Published: 5 January 2022

Publisher's Note: MDPI stays neutral with regard to jurisdictional claims in published maps and institutional affiliations.

Copyright: (C) 2022 by the authors. Licensee MDPI, Basel, Switzerland. This article is an open access article distributed under the terms and conditions of the Creative Commons Attribution (CC BY) license (https:// creativecommons.org/licenses/by/ $4.0 /)$.

\begin{abstract}
In the framework of this contribution, and taking a macro-historic sacred landscapes approach, we established a comparative project analysing in parallel the development of sacred landscapes of two mega-islands, Cyprus and Sardinia, at the transition from the Bronze to the Iron Age. In both Cyprus and Sardinia, the period between the 12th and 8th centuries BC seems to have been a time when re-negotiations of individual, societal, and political identities took place, and this is clearly reflected on the construction of the sacred landscapes of the two islands. We first present our 'landscape/macro-historic approach'; we then define the chronological horizon and the sociohistorical contexts under discussion for each island, exploring at the same time how the hierarchical arrangement of ritual sites appearing at this transitional phase seems to be related with articulated social order or linked with shifting relations of power and cultural influence. Finally, we proceed to a discussion addressing the following three questions: (1) what is the relation between individual insularities and the construction of sacred landscapes on these two mega-islands?; (2) how can a 'landscape/macro-historic approach' assist us in better formulating microscopic approaches on both islands at the transition from the Bronze to the Iron Age?; and (3) is a comparative approach viable?
\end{abstract}

Keywords: Cyprus; Sardinia; sacred landscapes; insularity

\section{Introduction}

Traditionally, historians and archaeologists concerned with the insular communities of ancient Cyprus and Sardinia have often treated ritual and religion as a sub-system of society, describing its material manifestations (sanctuary architecture or votive assemblages) and focusing on one particular chronological period (Papantoniou 2012a, p. 65; Ialongo 2013, p. 187; Depalmas et al. 2016). Thus, the active role of ritual and religion in the construction and transformation of social identities in the long term and their relationship with internal and external influences and power have been undervalued. Changes in ritual systems did not take place overnight. In order to understand ritual and religion as transcultural phenomena, particularly through major phases of socio-political transitions, it is essential to grasp both continuity and change.

The connections via trade between the Bronze Age cultures of Cyprus and Sardinia have been discussed on various occasions (e.g., see more recently Depalmas et al. 2017; Russell and Knapp 2017; Lo Schiavo 2018; Charalampous 2020; Gradoli et al. 2020; Sabatini and Lo Schiavo 2020; Knapp et al. 2021), and this is not the objective of the present comparative approach. The reason for choosing these two mega-islands at the edges of Mediterranean for a comparative approach is not to observe connections in ritual and cult; by taking a landscape approach, rather than focusing on specific sites, it is our intention to contrast Cyprus and Sardinia with regard to the place of the sanctuaries and their material culture in the landscape and their archaeological and social contexts. Landscape archaeology is an area of study that crosses conventional boundaries between disciplines, opening a window to the study of the past across time and space. The study of sacred 
landscapes is concerned with the study of the temporality, spatiality, and materiality of sacred space through time, using a range of interdisciplinary approaches (Papantoniou et al. 2019, with references). Our previous research has placed great emphasis on the interaction between political and religious structures, noting the importance of sacred landscapes in establishing social power and identity (e.g., Papantoniou 2012b, 2016; Depalmas 2014, 2018a; Depalmas et al. 2016; Papantoniou and Kyriakou 2018). In the framework of this article, and taking a macro-historic sacred landscapes approach, we established a comparative project analysing in parallel the development of sacred landscapes of two mega-islands, Cyprus and Sardinia, at the transition from the Bronze to the Iron Age.

It is generally accepted that the transition from the Late Bronze to the Early Iron Age is a period that comes after general disorder and movements of people and ideas in the broader Mediterranean, as well as in Cyprus and Sardinia, resulting in a kind of new cosmopolitan settlement (Knapp 2008; Georgiou 2012; Iacovou 2013; Ialongo 2017; van Dommelen 2018, p. 219; Georgiou and Iacovou 2019; for a comparative chronological table with correspondences between Cyprus and Sardinia, see Russell and Knapp 2017, p. 4). We have chosen this specific phase as the focus on this contribution as, as we will demonstrate below, this is the time that the sacred landscapes of the two mega-islands totally transform. Towards the end of the 12th century BC, Cyprus began to witness major transformations, which should, at least in part, be related to newcomers from the Aegean post-palatial world, possibly also from the Levant, who arrived as immigrants (rather than colonists) in the island's Late Cypriot urban centres. During the last phase of the Late Cypriot and during the Cypro-Geometric (ca. 1050-750 BC) periods, negotiations of individual, societal, and political identities took place, instigating the establishment of a new political geography on the island.

In Sardinia, during the Final Bronze Age (ca. 1150-950 BC), the construction of typical Bronze Age architectural structures named Nuraghe (housing towers) and collective monumental tombs known as Giants' Tombs slowly stopped. The population moved into villages representing the only form of settlement in the Early Iron Age. The Nuraghe were used as food stores or for cult rituals, although in rare cases, they continued to be inhabited. There are no traces of deliberate destruction but only of abandonment. The most important phenomenon of the period is related to the construction of places of worship. In fact, the earliest 'Nuragic' sanctuaries were built during the Final Bronze Age and at the beginning of the Early Iron Age (ca. 950 BC): these are centred on monuments built over springs or deliberately dug wells. Settlements of different sizes often grew up around these temples (Blake 2001). Many of these were probably only used when the local community came together to participate in the festivals and religious ceremonies that took place at the sites. In the Final Bronze Age, we can notice substantial societal changes. Social stratification appears and consolidates in the Iron Age. In Sardinia, although the term Nuraghe has also long been widely used to define the Final Bronze and Early Iron Age phases, it should be remembered that the Nuragic period proper would include only the Middle and Recent Bronze Age, which coincides with the period of construction and primary use of Nuraghi. In this sense, the phase relating to sanctuaries and worship, i.e., the Final Bronze and Early Iron Ages, should not be defined as Nuragic.

\section{Cypriot Sacred Landscapes through Time}

Ritual practice on Cyprus prior to the beginning of the Late Bronze Age (ca. 1700 BC) has been identified primarily in the mortuary domain, which seems to have functioned as a key setting for the origins of cosmological systems (Webb and Frankel 2010). As Webb (2019a, 2019b; cf. Bürge 2021) has convincingly argued, the institutionalisation of ritual and the development of related ideologies and iconographies in the Late Bronze Age seem to derive from earlier, more socially integrative practices and should be seen as a response to emerging urbanisation and economic intensification. The study of pre-Late Bronze Age ritual, therefore, serves to capture the indigenous elements of Cypriot culture (Papantoniou 2016; Papantoniou and Webb 2021). 
During the Late Bronze Age (ca. 1700-1100 BC), ritual landscapes became increasingly linked to industrial activities. The appropriation, distribution, and consumption of various resources (especially copper), labour, and land were achieved by the elite through exploitation of supernatural knowledge (Knapp 1986, 1996, 1999; Webb 1999, 2001, 2014). Divine figures standing on the ingots (Figure 1), as well as the direct spatial relation between copper workshops and sanctuaries in the case of Kition, for example, have been widely discussed in the scholarship on the construction of an argument around the relationships between economy and religious institutions (for a literature review, see Kassianidou 2005).
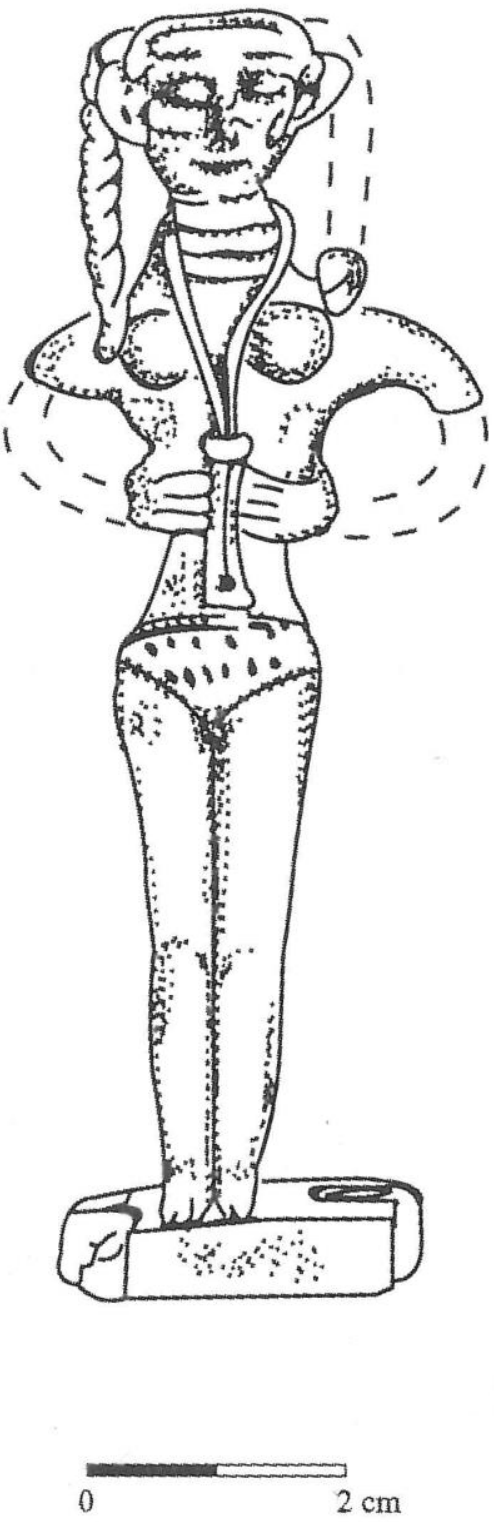

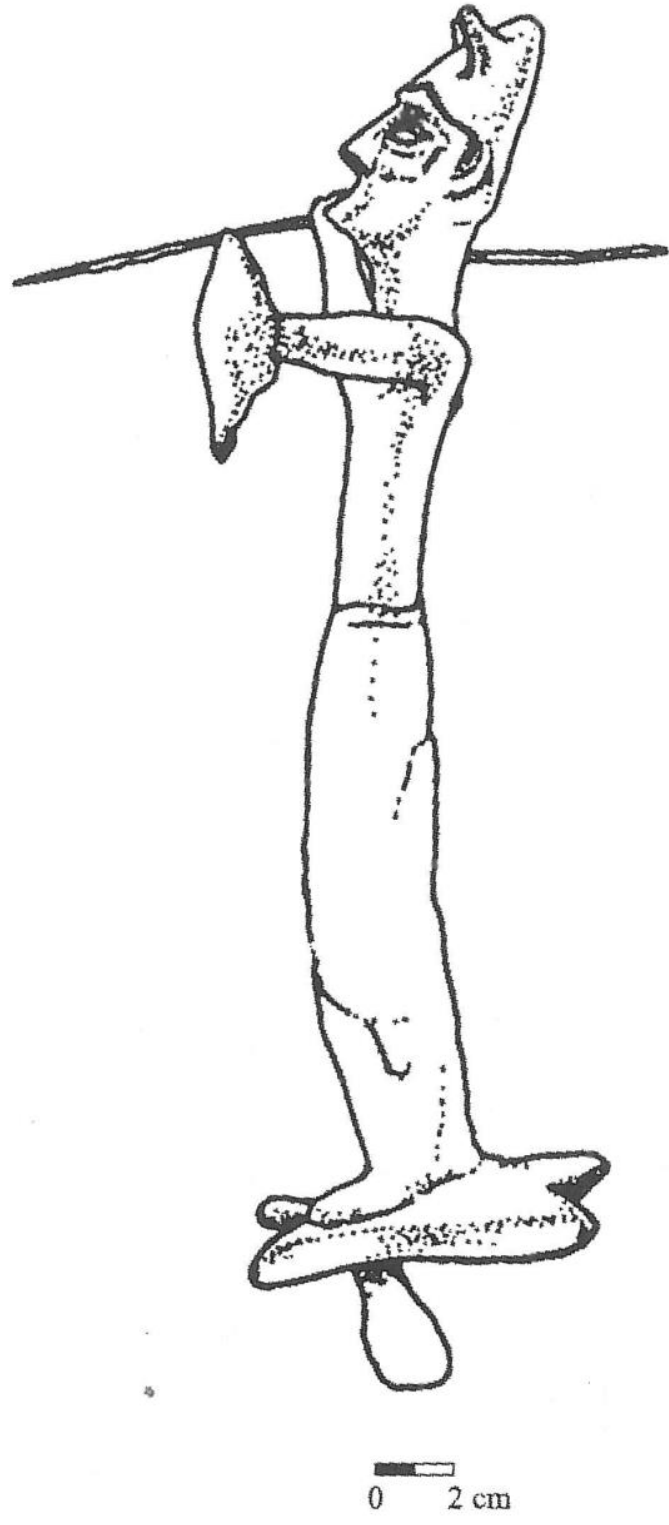

Figure 1. The so-called 'Bomford Goddess' (left) and the 'Ingot God' of Enkomi (right) (after Webb 2001, p. 75, Figure 6).

Considering that the foundation horizon of the Cypriot Iron Age polities lies well within multi-layered socio-political transformations, the statements above should be kept in mind as one moves towards Iron Age ritual and sacred space. In this context, it is particularly important to introduce issues of memory into the discussion by noting that a number of Iron Age sanctuaries were built within the ruins of Late Bronze Age monuments. At Agia Irini, for example (Figure 2: no. 9), an Iron Age temenos was built on top of the 
ruins of a Late Bronze Age settlement (for the Early Iron Age evidence for sacred landscapes and a literature review, see Papantoniou 2012b).



Figure 2. Hypothetical map showing the synchronicity of Cypriot kingdoms (as independent polities) and sanctuary sites at the transition from the Archaic to the Classical period, illustrating the problems involved in an attempt to capture political and sacred landscapes at a single point in time during the Iron Age (cost surface GIS analyses conducted by converting slope inclinations derived from the DLS DEM to time cost per unit surface area travelled based on exponential anisotropic Tobler's hiking function). Sanctuary numbers on the map correspond with site names published in the online appendix of (Papantoniou 2013b): www.ajaonline.org/article/1493; accessed on 17 December 2021. Digital data courtesy of the Department of Geological Survey and the Department of Lands and Surveys (map and analysis by Charalampos Paraskeva).

The Early Iron Age political and sacred landscapes (between the 11th and 8th centuries BC) are very difficult to comprehend (Papantoniou 2012b, pp. 306-7; 2016, p. 77; Iacovou 2013). Nonetheless, one should highlight two significant changes in the perception of ritual space that took place within this period: (a) the consolidation of the Cypriot urban and extra-urban Iron Age temenos type with specific religious and public roles/purposes; (b) a clearer separation of 'secular' and 'religious' urban space, but still always in direct ideological relation and association. Based on the current stage of research, this suggestion cannot be applied as a model for each and every Iron Age polity; each site had its unique development and individual history, based primarily on its surrounding geography. A fact remains, however: we can identify temenos sanctuary sites (that is an open court, enclosed by a peribolos wall, with an altar and sometimes a rectangular room) in urban and rural environments only towards the end of the Geometric period, that is at the same time as when we can notice palatial structures on the island. This phenomenon might well relate to the consolidation of the Cypriot city-kingdoms and their territories.

It is important to note that the transition from the Late Bronze Age to the Early Iron Age is the first time in the history of the island when a terracotta female figurine, that is the so-called 'goddess with upraised arms' type (Figure 3), is found in a clearly religious (not just ritual) context. For example, in its last phase, the sanctuary of the 'Ingot God' at 
Enkomi (near the later city of Salamis) was equipped with offering benches and the west 'adyton' housed a baetyl (an aniconic stone image of the deity) surrounded by many votive objects, including several figurines of the 'goddess with upraised arms'. The origin of this type is often attributed to the 'post-Mycenaean' or 'sub-Minoan' (non-palatial) worlds. D'Agata, however, is right to suggest that comparative stylistic studies can take us no further than mere observation of the 'migration' of the type (D'Agata 2005, p. 9). Moving beyond stylistic analysis, however, the analysis of the archaeological stratified evidence for Enkomi and other sites such as Kition or Palaipaphos shows that this type of figurine, along with other representations, does not seem to corroborate the argument that, during the 12th and 11th centuries BC, the two major islands of Crete and Cyprus were involved in a particularly noteworthy exchange at the level of actual cultic or ritual practices. Rather, these stylistic relations may reflect the trade circuit at work between Cyprus and Crete within the context of wider ranging contacts with the Mediterranean world (D'Agata 2005, p. 14; cf. Kourou 2002, pp. 32-33; Zeman-Wisniewska 2013) (for detailed discussion and further references, see Papantoniou 2016, pp. 84-92; cf. Papantoniou 2013a; Budin 2014, pp. 204-5).
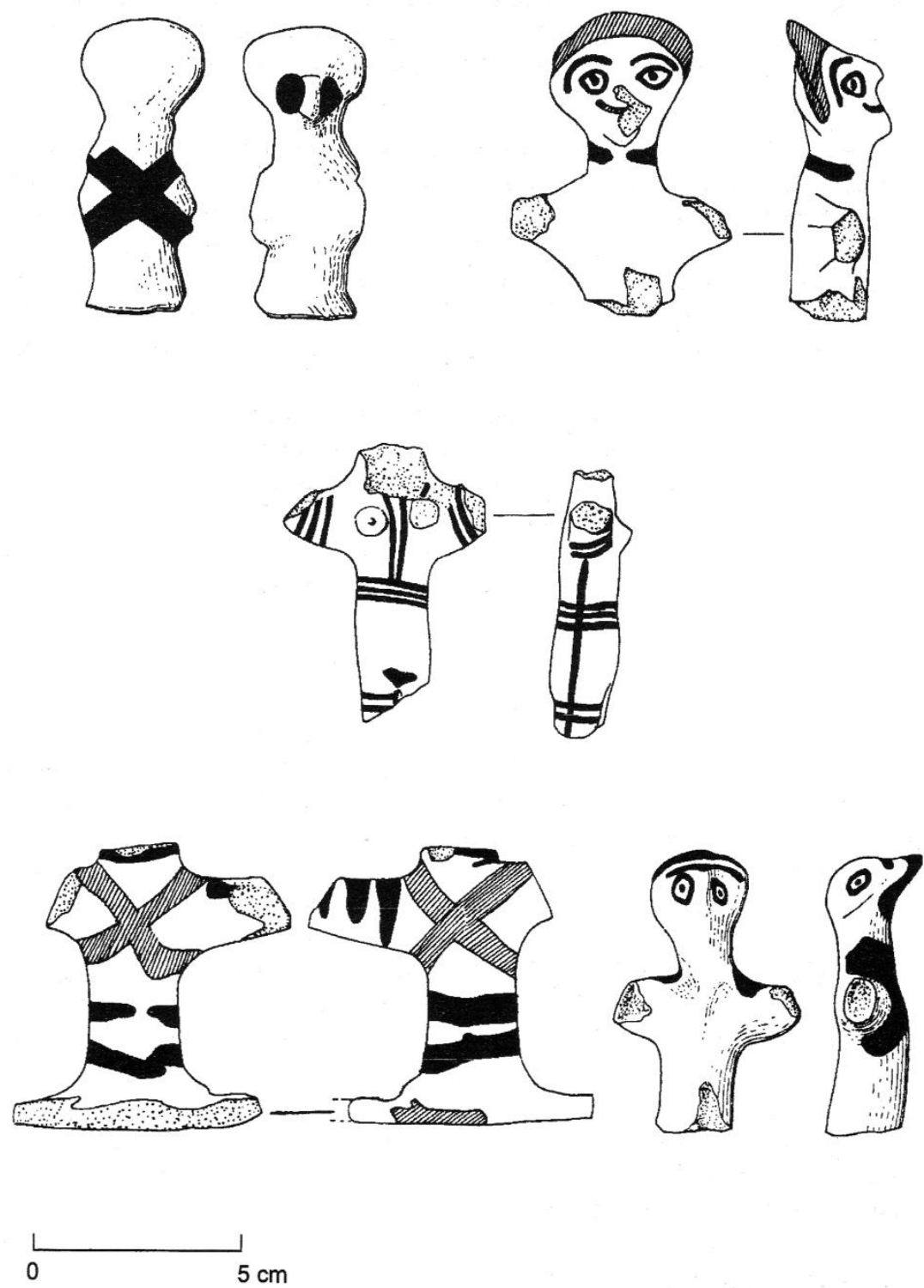

Figure 3. Terracotta figurines of the 'goddess with upraised arms' type from the sanctuary of the 'Ingot God' at Enkomi (after Webb 1999, p. 214, Figure 75). 
The multiplication of the extra-urban sanctuaries in early Archaic times represents the climax of a process that started within the Geometric period. While urban sanctuaries became communal religious centres where social, cultural, and political identities were affirmed, the extra-urban sanctuaries played an important role in the establishment of the political and territorial boundaries of the many co-existing Iron Age polities of the Archaic and Classical periods of the 8th to the 4th centuries BC (Papantoniou 2013b). It is probably not accidental or results only from access/or non-access to limestone quarries that the best corpus of monumental limestone sculpture of Cypriot dignitaries or even of probable 'royal types' comes from extra-urban sanctuaries (Satraki 2012), especially those located in the plain of the Mesaoria, where many polities would have vied for territorial control.

Sanctuaries were diachronically instrumental within the power systems and the construction of the political geography of Cyprus. An examination and analysis of sacred landscapes in the longue durée provides information on how various agendas and ideas were communicated and transmitted and allows multiplicity and diversity in their interpretation. Whether particular extra-urban sanctuaries intentionally marked 'boundaries' remains hypothetical and problematic; a macro-historic approach, which examines the Cypro-Archaic city-kingdom sacred landscapes vis à vis those of the earlier and later periods, can provide a different framework for understanding the function of extra-urban sanctuaries in the territoriality of the Iron Age polities (Papantoniou 2019, with references). Nonetheless, lying within extra-urban settlements, along long-distance communication routes or in 'frontier' zones, they were linked to evolving sociopolitical and socioeconomic dynamics, creating 'liminal' zones among the city-kingdoms. Geographic Information Systems (GIS) analyses of the distribution of city-kingdom sanctuaries (Figure 2) have revealed their diachronic relationship with roads, sociopolitical 'boundaries', and networks, and with communication and trade routes between city-kingdoms or cities, second-rank towns, and rural settlements (Papantoniou and Kyriakou 2018; Papantoniou 2019; cf. Papantoniou and Bourogiannis 2018; Papantoniou and Vionis 2018; Vionis and Papantoniou 2019).

\section{Sardinian Sacred Landscapes through Time}

As early as in the full Middle Bronze Age (ca. 1700-1350 BC), refined techniques for cutting and polishing squared building blocks indicate a new, fine taste and specialised craftsmanship, expressed (as in the case of the Cypriot Bronze Age) first in funerary monuments and later, during the Final Bronze Age and the Early Iron Age (ca. 1150-750 $\mathrm{BC}$ ), in specific buildings dedicated to worship (in a similar way as the Cypriot Iron Age temenos). During the Middle and Recent Bronze Age (ca. 1350-1200 BC), monumental collective tombs named Giants' Tombs, were erected. Giants' Tombs are the buildings where communal rituals, feasts, and ceremonies for the dead take place. In particular, the open space shaped in a semi-circular area (exedra) located in the front of tombs coincided with the ceremonial zone. Like the Nuraghi, the Giants' Tombs also seem to have stopped being built by the Final Bronze Age. At the same time, it is possible to observe the rise and development of sanctuaries and places of worship focused on springs or wells or, in any case, buildings connected with water, as well as the spread of structures for community ceremonies such as rotundas or meeting huts. The emergence of monumental complexes and structures expressly designed for rituals and ceremonies is directly linked to the diminishing role of the Giants' Tombs as the location of religious ceremonies.

In contrast to the dense settlement patterns of the Middle and Late Bronze Age, in the Final Bronze Age and the Early Iron Age, the 'Nuragic' sanctuaries gathered different communities creating new types of networks (Depalmas 2014, 2018a; Usai 2015; Matta 2020). These cult complexes are diverse and often associated with the use of water, maybe due to climatic reasons: we can categorise Sardinian religious buildings as: a. sacred wells and springs; b. rectangular buildings (megaron temples); c. straight-and curvilinear structures; and $\mathrm{d}$. circular buildings, in some instances featuring so-called 'rounds with basins' or without any vats (Depalmas 2005). 
As already mentioned, the Sardinian Iron Age communities were organised in independent villages apparently with no substantial differences in size or rank, and not organised politically under bigger units (Depalmas and Melis 2010; Depalmas 2017). The exact function or functions of these sanctuaries in the context of these villages and their territorialisation remains to be identified. As with the building of the Iron Age Cypriot temenos with its role as a public sanctuary, the building of cult structures in the Final Bronze Age (ca. 1150-925 BC) is also a completely new phenomenon in the Sardinian landscape. Around the temples, groups of huts of varying sizes were established and probably often used by pilgrims at the feasts and religious ceremonies that attracted many communities from the whole territory, in a similar fashion to modern Christian sanctuaries nowadays in the Sardinian countryside.

We do not know the precise ceremonies that were practiced around the water cult sanctuaries; however, thanks to archaeological contexts, we can reconstruct a ritual involving the roasting of animal offerings, probably as part of religious feasts. The few archaeological contexts in Sardinia that have yielded useful finds show the presence of bones of wild and domestic animals, some of them burnt, leading to the hypothesis of a liturgy probably during ritual meals. In particular, the analysis of the faunal remains found in association with the pottery and the iconography of the bronze statuettes, representing worshippers offering gifts such as animals, food, and pottery (e.g., those from the sanctuary of Abini mentioned below) allow us to support the hypothesis of such offerings and ritual performances in Sardinian protohistoric sanctuaries (Depalmas et al. 2021). Another important source of information for understanding the rituals carried out in these sanctuaries is the class of small bronze figurines, the so-called 'bronzetti' (Figures 4 and 5), mainly found within cult areas and interpreted as offerings given to the temple during ceremonies (Ialongo 2013). In addition, one of the most commonly depicted subjects is the worshipper offering animals (rams), objects, and food.

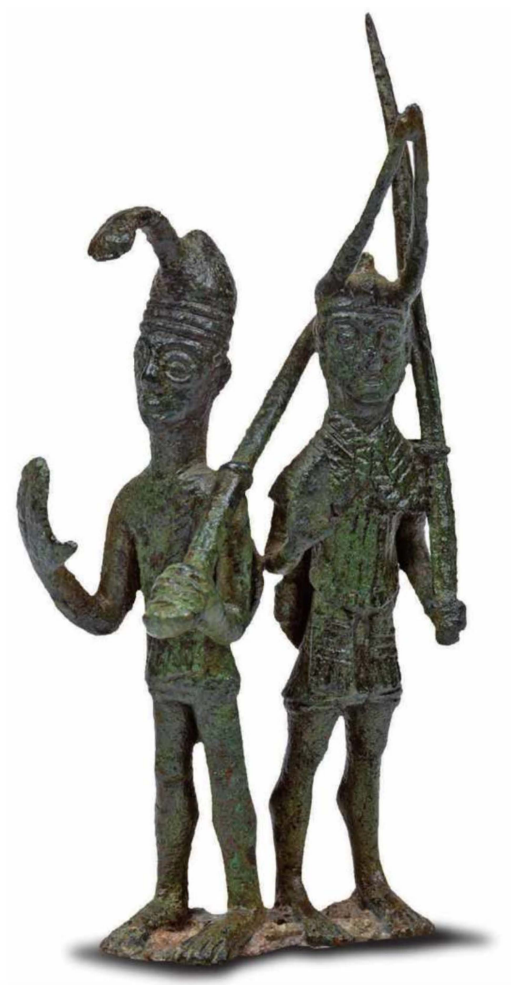

Figure 4. 'Bronzetti' from Abini 'Nuragic' sanctuary in Teti (from Canino 2014, p. 351). 


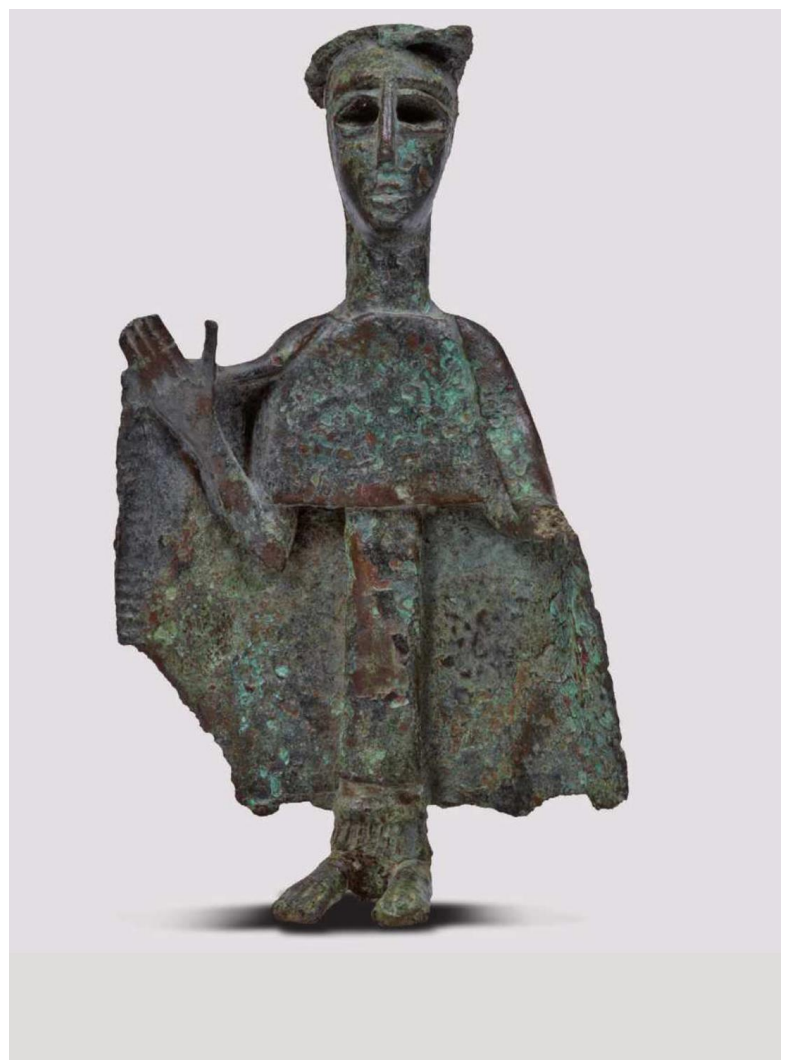

Figure 5. Woman offerer from the hoard of S'Arrideli in Terralba (from Alba 2014, p. 384).

The sanctuaries, or the village close to them, would have had an important and primary role in metallurgical activities for the production of metal weapons, tools, and objects (Depalmas et al. 2016, pp. 345-48). As well as figurines, a large number of weapons have been found in so-called 'Nuragic sanctuaries' (mainly daggers and 'votive' swords), tools, and objects, often in miniature (Lo Schiavo 1992), and these allow us to classify the well, the spring, the rectangular or circular building, and other connected rooms as places of metal artefact collection or even (in some instances) production (Depalmas 2018a, p. 8). The deposition of weapons in votive sanctuary contexts corresponds to precise offering sets, in which pins and daggers are recurrent; their presence has been interpreted as a personal offering, which corresponds to the funerary equipment in other geographical areas, and so is related to the social status of the donor. As discussed above, one can notice similar votive practices related to status in the case of the Cypriot Iron Age temenos. As Ialongo (2013) clearly asserts, Sardinian elites presented a complex 'ritual strategy', so that they could seize political legitimacy and territorial economic organisation. The water sanctuaries show the power and wealth of 'Nuragic' communities through the monumentality of their structures, their elaborate stone decoration, and the presence of exclusive built-in stone furniture and votive offerings. The management of the sanctuary by the elites took place through the involvement of the local communities in the ceremonies and feasts associated with them, which constitute a powerful attraction for goods and people.

In any case, water sanctuaries were centres of not only religious value, but also of political, economic, and social significance, since the Sardinians met at them to govern society and to manage wealth and resources (Depalmas 2018a, pp. 9-10). In addition to locally produced objects, mainly weapons, tools, ornaments, and figurines, the presence of fibulae of peninsular origin is well documented (Figure 6). These were evidently dedicated to the temple as a result of contacts with the Villanovan area, although Sardinian sanctuaries also received fibulae dating from the Final Bronze Age as votive offerings (e.g., in Santa Vittoria di Serri, Serra Niedda di Sorso) (Salis and Minoja 2015). It is certainly significant that the deposition of fibulae in graves is almost unknown, given that the only finds in 
funerary contexts come from the necropolis of Monte Prama, and moreover from outside a shaft burial (Lo Schiavo 1992). This reinforces the idea that dedication of these objects to the temple follows the perspective of the offering as an exotic object whose functional value is not maintained, although it is also possible that the fibulae were deposited as part of an offering of a textile or item of clothing.

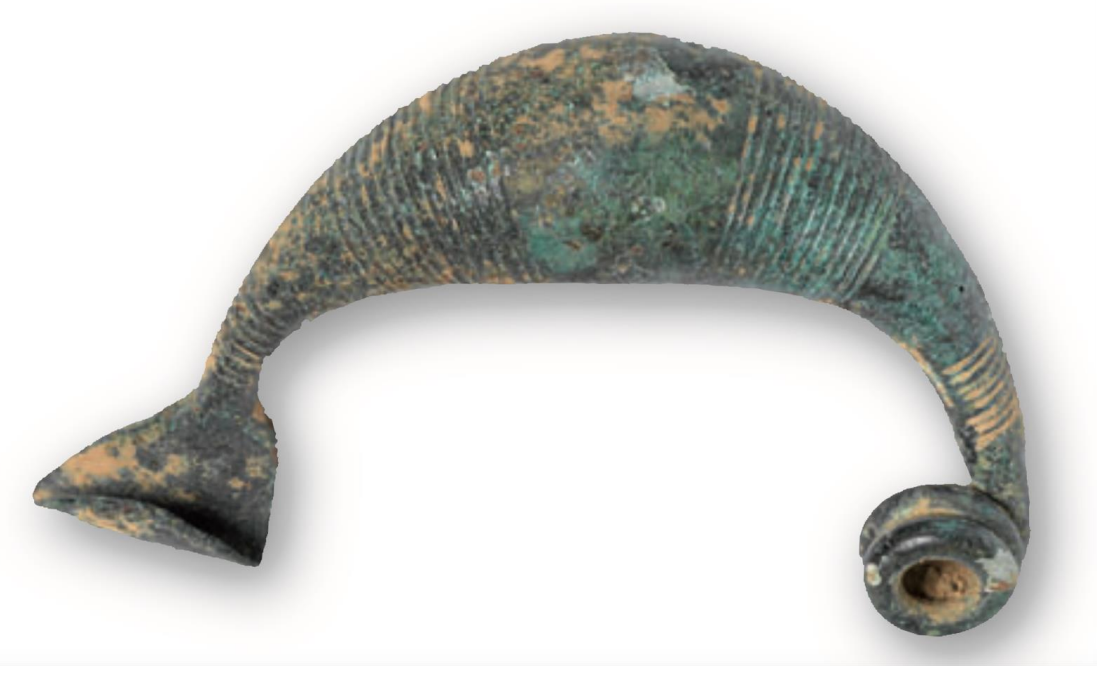

Figure 6. Fibula from cult complex of Sa Sedda 'Sos Carros in Oliena (from Gianfranca Salis 2014, p. 285, n. 27).

Spatial analyses, such as Network Analysis and GIS, support the interpretation that these Sardinian landscapes, similarly to the Cypriot case, acted as symbolic, economic, and territorial nodes within and in-between settlements and various natural resources (Matta 2020) (Figure 7). Even if they still lack an agreed scholarly interpretation, beyond their function as centres of religious and political aggregation of dispersed communities, 'Nuragic' sanctuaries seem to have been placed at strategic locations of several variables related to the environment, centrality, territoriality, and economy (Depalmas 2014; Matta 2020, p. 92). The interaction with groups coming from outside, such as the Phoenicians, who began to frequent the coasts of the island at least from the beginning of the Iron Age, seems also to be reflected in the internal dynamics of the sanctuaries, which appear to be centres able to attract exotic goods, probably always in the context of offerings dedicated at the temple. It is also possible, according to new models, that these arrived from outside, via emporia (van Dommelen 2018, pp. 219-21), in some cases perhaps coinciding with sanctuary sites, such as Sant'Imbenia in Alghero (for the hypothesis of the presence of an indigenous sanctuary in the site, see Depalmas 2018b, p. 119). Significant here is the presence of bronzes featuring iconographies of oriental divinities in cult complexes such as those of Santa Cristina in Paulilatino and the Camposanto in Olmedo (Tore 1983) or Nurdole in Orani (Madau 1997), testifying to the role and the force of attraction played by the sanctuaries of the inland areas with regard to the coastal areas as well. 


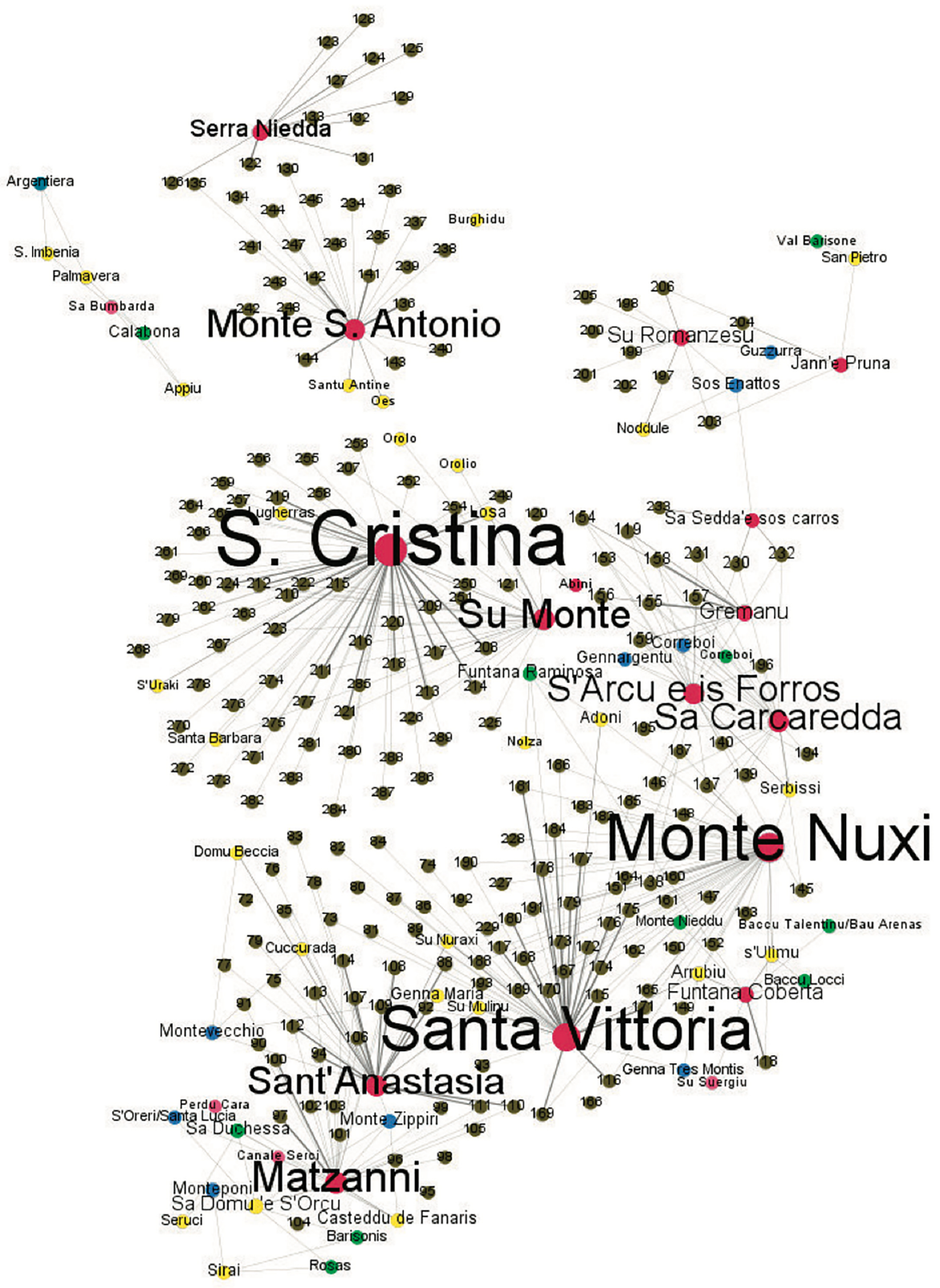

Figure 7. Network graph showing the connections between sanctuaries (in red), major settlements (yellow), other Nuragic settlements (brown), and ores (green, blue, pink) (from Matta 2020, p. 121, Figure 5).

\section{Discussion}

Having presented the evidence first from Cyprus and then from Sardinia from the Bronze to the Iron Age, we conclude by addressing the following three questions:

4.1. What Might Be the Relation between Individual Insularities and the Construction of Sacred Landscapes on These Two Mega-Islands?

What we have been able to show is that within their Late Bronze Age and Iron Age insular systems, both Cypriot and Sardinian sanctuaries, as is the case in other areas of the Mediterranean and world religion (e.g., see case studies in Papantoniou et al. 2019 with references), were centres not only of religious importance, but also of political, economic, and social significance, acting as central places where communities from the broader territory would have met, and where social and political identities were manifested and maintained. 
Archaeologically, when it comes to sacred landscapes and religious material culture, Cyprus and Sardinia have revealed distinct identities shaped both by isolation and connectivity with the external world. For example, if we take the so-called 'goddess with upraised arms' figurines from Cyprus, we can note that it is influenced by the Aegean, but at the same time, they acquired a specific identity and meaning within their own insular systems (Papantoniou 2016). In Sardinia, the constant presence among the offerings of the sanctuaries of materials imported from outside, especially from the Italian peninsula, such as Villanovan fibulae, indicates not only the intense relations between the two opposite sides of the Tyrrhenian Sea, but also the tendency to take over and give new meanings to this material (Salis and Minoja 2015). Island size and proximity to the mainland and other islands can influence the nature of insularity and connectivity (Gordon 2018; Knodell et al. 2020), in this case the levels of transmission and transformation of culture (Clarke 2005). The ways in which materials, ideas, and behaviours are transmitted and transformed in time and space have usually been explored by historians and archaeologists who tended to focus on trade and exchange, immigration, colonisation, cultural diffusion, acculturation, and enculturation. Modern scholarship has been particularly keen on identifying and understanding the complex web of other interactions, transmissions, and transformations that happen when processes such as trade, exchange, military conflict, and social disorder take place, as well as the multiplicity of social changes that result from such phenomena (Schortman and Urban 1992; Clarke 2005; Knapp and van Dommelen 2010): movement of people and social disorder, trade and exchange, all of which are related to the transition from the Bronze to the Iron Age in the Mediterranean, are deeply linked to the way in which culture is transmitted and transformed. Agency and objectification processes also need to be considered in order to comprehend ancient cultural systems, artefacts and their meanings, as well as ancient cognitive systems and sacred landscapes. It should, thus, be remembered that any artefact can give rise in different viewers to a multitude of varying and even contradictory perceptions, responses, and meanings, depending on their personal experience and identity (Elsner 1995, p. 3).

Movement of objects and ideas through space via migration, trade, exchange, etc. appear to enhance or promote change. Cultural traits, therefore, travel with people, but not all aspects of culture travel in the same way. A 'receiving group', for instance, can easily copy materials, decorative styles, and iconography, and these kinds of cultural transmissions are more clearly identifiable in the material record. Technologies and ideologies, including religion, require greater human participation in the transmission process, and they are harder to identify. When transmitted, such cultural forms can also be transformed. An important problem, however, in cultural transmission and transformation studies is identifying the level of human participation in the process. While style, for instance, can be transferred without the presence of people who have actual knowledge of it, the adoption of new technologies or ideologies apparently requires the presence of people who can demonstrate ways of doing things and ways of thinking about them. It is indeed very difficult to grasp the complexities of human interaction without first understanding the types of cultural transmissions and transformations that have occurred in a local context. Culture is created by experience shaped by various interactions with the world around, and it should be emphasised that the concept of 'local context' is very important in this process. The role of memory in the transmission and transformation of culture becomes an important interlocutor (Rowlands 1993). Mega-islands, such as Cyprus and Sardinia, therefore, produced different sacred landscapes and religious material culture, which were largely self-sufficient.

4.2. How Can a 'Landscape/Macro-Historic Approach' Assist Us in Better Formulating Microscopic Approaches on Both Islands at the Transition from the Bronze to the Iron Age?

Such an approach shows that, in the cases of Cyprus and of Sardinia, a Bronze Age cult practice was transformed and transplanted into the Iron Age due to its association with a successful indigenous political and economic model based on the elite manipulation 
of power, including the production and circulation of metals and other resources. In using the terms 'transplantation' and 'transformation', we refer to the transfer of earlier ideas (and ideals) — as read in ritual practices, cult, and iconography—into an Iron Age sacred landscape, functioning within the context of a newly emerged political/administrative topography. Material evidence and iconography, as described above, allows us to identify sacred space in a given territory and to reconstruct sacred landscapes in which natural and/or manmade features were endowed with religious meaning. In addition, we can investigate how the two different cultures under discussion saw the relationship between natural resources, human constructions, and the supernatural, how the environment was changed or manipulated to construct a sacred landscape, and how the 'acculturation' process or forms of interpretatio religiosa resulted in changes to the sacred landscapes. In order to value 'religion' on these terms, we must question where the 'secular' and the 'sacred' begin or end and consider how it might be possible to isolate the 'sacred' from its socio-cultural matrix. The emergence and establishment of spatial analysis as a new field of study has put space at the centre of historical analysis. Sacred spaces, previously usually overlooked or studied as single sites irrespective of their built and natural environment, are now seen as sites of historical processes within a broader socio-political landscape and environmental framework (Papantoniou et al. 2019).

However, the relationship between ritual and community should be singled out. Materials used in ritual and votive practice, such the 'goddesses with upraised arms' figurines in the case of Cyprus or the Villanovan fibulae in the case of Sardinia, express the reception of this relationship by the public. Power and knowledge are closely linked, and the interaction between the population and political structures needs to remain our primary concern when we attempt to interpret ancient power structures. These concerns are closely bound to issues of the interaction between popular and politico-religious identities. The audience of both the Cypriot and the Sardinian sanctuaries must have taken ownership of the reception of any interaction, otherwise the message would be lost. Trends and iconography, therefore, were always translated into and reworked within Cypriot and Sardinian island traditions in order to express both elite ideology and popular cosmology.

\subsection{Is a Comparative Approach Viable?}

A comparative approach is viable not because there is any concrete evidence for direct interaction between the two mega-islands, but mainly because we are focusing on two mega-islands, behaving differently and more independently in relation to other smaller islands in the Aegean Archipelagos or the Croatian coast, for example. In addition, studying macro-historically the sacred landscapes of the two mega-islands, we can observe similar behaviours or functions of the sanctuaries, although, in each case, in a very different sociopolitical setting. Mega-islands may offer their own continental feeling, exactly because they are mega rather than being studied from the external vantage point of continental realms; thus, each mega-island can provide special insights into larger processes of socio-political responses, global or local (Hadjikyriacou 2017, p. x). Reminiscent of mainland areas with plateaus and mountain ranges, areas that Braudel (1972, pp. 160-61) called 'islands that the sea does not surround', 'sea-girt islands are landmasses marked by fluctuating levels of social connectivity and isolation' (Gordon 2018, p. 5); i.e., they can be places where social processes are either difficult to observe on continental space, or qualitatively variant on such mega-islands. Following Knapp (2008, pp. 373-86), local resources, seascape, and geopolitical location can create unique-and archaeologically legible-identities. Such an approach can contribute to a discourse on insularity, especially through its examination of long-term biogeographic and short-term socio-cultural configurations (Gordon 2018, p. 5).

The concept of 'islandscapes' (involving the sea and the coasts) becomes even more vital when studying such mega-islands, where the landscapes and coastlines are experienced differently by people living on the same island and may include a diverse range of 'temporal' and 'spatial' features (Gordon 2018, pp. 21-22). Thus, each Cypriot polity should be seen as an individual micro-entity (to use the term metaphorically, as if a small 
islandscape) within the unitary space of the Cypriot mega-island, and each Sardinian post-Nuraghi society should be seen as an individual micro-entity island within the unitary space of the Sardinian mega-island. The cultural unity of the Cypriot polities and the Sardinian settlements seems to rely on a multi-layered composition of regional variability created by inter-regional influences, while the stylistic and architectural comparisons between the various centres should be viewed vis à vis other material culture indicators and topographical features. In other words, in each centre, we find architectural and material similarities between sanctuaries, but also regional variation (Papantoniou 2012a, pp. 21, 106; Depalmas 2018a). The clusters of Cypriot and Sardinian sacred landscapes (Figures 3 and 4) further showcase the idea of multiple islandscapes making a connected mega-island. In understanding such mega-islands, one has to consider first the differing levels of connectivity and isolation influenced by external contact (or non-contact if we consider the landward buffers beyond seascape and established views on the relative distance of Sardinian parts from the continental shores) (cf. Vogiatzakis et al. 2017), and secondly, long-term local practices in the case of each island. It appears that there could have been a range of islandscape-based notions of insularity that would have affected Cypriot and Sardinian sacred landscapes and their material expression, allowing for a great degree of local insular developments at the transition from the Late Bronze Age to the Early Iron Age (cf. van Dommelen 1998, pp. 11-13; Kearns 2018; Dawson 2019; Russell 2020). The development of major coastal sanctuaries in the seascape of Cyprus during the Late Bronze Age, at Kition and Palaipaphos, continuing into the Iron Age, the Hellenistic and the Roman periods, in parallel with other major coastal sanctuaries at Amathous, Salamis, Soloi, and Kourion, for example, further supports this statement, relating to topographical features, seascape connectivity, and landward isolation. Most Sardinian sanctuaries originated in the Final Bronze Age, if not the Recent Bronze Age, and developed during the Early Iron Age, elaborating complex forms of organisation through the establishment of complex rituals, the control of metallurgical workshops, and the management of considerable wealth including objects of external provenance such as amber, bronze, and fibulae. Sanctuaries were also places of attraction and sites of meetings with Phoenician components that came from the coast to inland areas, as is well exemplified by the sanctuary of Santa Cristina, where, in addition to Villanovan fibulae, there are Levantine elements represented not only by Phoenician ceramics but also by figures of seated deities.

\section{Conclusions}

This article represents a first attempt to develop a comparative approach between Cypriot and Sardinian sacred landscapes, and to explore what lessons we can learn from such an approach. Our contribution contrasts Cyprus and Sardinia with regard to the place of sanctuaries and their material culture in the landscape and the archaeological and social contexts. There is clearly much more space for future research and developments using and developing this approach. Broadening our scope to the cosmopolitan settlements that emerged after the Early Iron Age Mediterranean movements (van Dommelen 2018, p. 227), through the study of material culture deriving from these sacred landscapes, we may be able to explore the broader array of cultural interaction at both local scale and interregionally in the Mediterranean, asking questions about the nature of the evolving worlds in a local context, full of material or ideological connectivities, as seen in the material culture from Cypriot and Sardinian sanctuaries presented above. Some of the insular variables that shaped Cypriot notions of insularity (size, ports, and seafaring history) may have parallels on Crete or Sicily, while the range of its natural resources is closer to Sardinia (Gordon 2018, p. 15). It is, however, the unique combination of each island's size, resources, and location in relation to contacts with continental cultures that likely played a key role in influencing spatially contingent notions of Cypriot and Sardinian insularities as expressed in sacred landscapes and their material culture, and as reflected in the periods afterwards (cf. Roppa 2018; Gordon 2020, p. 17; Kardulias 2020). Both in Cyprus and Sardinia, sacred landscapes seem to have played a significant role in the control of resources and the mobility 
of raw materials, as well as the territoriality of space. An island archaeology approach offers a framework for exploring the transition from the Late Bronze Age to the Early Iron Age, contextualising Cypriot and Sardinian sacred landscapes within a geohistorical situation that is unique to these sea-girt mega-islands (cf. Kopaka and Cadogan 2012, p. 23). In recent years, Cyprus, on the eastern margins of the Mediterranean, and in a number of publications, has emerged more and more often as an incompatible peripheral entity, whose archaeological record confirms its uniqueness, encouraging 'Cyprocentric' approaches that emphasise its long-term endogenous rather than exogenous cultures and historicity (Iacovou 2007; followed or commented by, e.g., Papantoniou 2012a, 2013a, 2016; Satraki 2012; Counts and Iacovou 2013, p. 17; Averett 2015; Gordon 2018, p. 8; Kearns 2018, p. 67). Perhaps the time is ripe, when it also comes to Sardinia, on the western margins of the Mediterranean, to move more clearly to similar 'Sardinocentric' approaches, free of neighbouring continental or contemporary nationally (i.e., Greek for the case of Cyprus, and Italian for the case of Sardinia) driven archaeologies, for insular interpretations of both 'Nuragic' and later historical sacred landscapes.

Author Contributions: Conceptualisation, G.P. and A.D.; methodology, G.P.; formal analysis, G.P. and A.D.; data curation, G.P. and A.D.; writing — original draft preparation, G.P.; writing-review and editing, G.P. and A.D.; funding acquisition, G.P. and A.D. All authors have read and agreed to the published version of the manuscript.

Funding: This research was funded by the University of Sassari 2016 Visiting Scientist Programme. In addition, part of this work falls under the Unlocking the Sacred Landscapes of Cyprus (UnSaLa-CY) research project, co-funded by the European Regional Development Fund and the Republic of Cyprus through the Research and Innovation Foundation (EXCELLENCE/1216/0362).

Acknowledgments: We thank Christine E. Morris for proofreading the English of an earlier draft of this manuscript, providing also valuable ideas. Finally, we thank the anonymous reviewers for their constructive comments and suggestions.

Conflicts of Interest: The authors declare no conflict of interest.

\section{References}

Alba, Elisabetta. 2014. Bronzi a figura femminile. In La Sardegna Nuragica Storia e Materiali. Edited by Alberto Moravetti, Elisabetta Alba and Lavinia Foddai. Sassari: Carlo Delfino, pp. 381-404.

Averett, Erin W. 2015. Masks and Ritual Performance on the Island of Cyprus. American Journal of Archaeology 119: 3-45. [CrossRef]

Blake, Emma. 2001. Constructing a Nuragic Locale: The Spatial Relationship between Tombs and Towers in BA Sardinia. American Journal of Archaeology 105: 145-61. [CrossRef]

Braudel, Fernand. 1972. The Mediterranean and the Mediterranean World in the Age of Philip II. Translated by S. Reynolds. New York: Collins.

Budin, Stephanie L. 2014. Before Kypris was Aphrodite. In Transformation of a Goddess. Ishtar-Astarte—Aphrodite. Edited by David T. Sugimoto. Orbis Biblicus et Orientalis 263. Fribourg: Academic Press Fribourg, pp. 195-215.

Bürge, Teresa. 2021. Mortuary Landscapes Revisited: Dynamics of Insularity and Connectivity in Mortuary Ritual, Feasting, and Commemoration in Late Bronze Age Cyprus. Religions 12: 877. [CrossRef]

Canino, Gianfranco. 2014. Bronzi a figura maschile. In La Sardegna Nuragica Storia e Materiali. Edited by Alberto Moravetti, Elisabetta Alba and Lavinia Foddai. Sassari: Carlo Delfino, pp. 347-80.

Charalampous, Rafail. 2020. Analogie, Differenze e Rapporti tra Cipro e Sardegna nel Corso Dell'età del Bronzo. Master's thesis, Università degli Studi di Sassari, Sassari, Italy.

Clarke, Joanne, ed. 2005. Archaeological Perspectives on the Transmission and Transformation of Culture in the Eastern Mediterranean. Levant Supplementary Series 2; Oxford: Oxbow Books.

Counts, Derek B., and Maria Iacovou. 2013. New Approaches to Elusive Iron Age Polities of Ancient Cyprus: An introduction. Bulletin of the American Schools of Oriental Research 370: 1-13. [CrossRef]

D'Agata, Anna Lucia. 2005. Cult Activity on Crete and Cyprus at the End of the Late Bronze Age and the Beginning of the Early Iron Age. What Comparative Analysis Can Tell Us. In Cyprus: Religion and Society. From the Late Bronze Age to the End of the Archaic Period. Edited by Vassos Karageorghis, Hartmut Matthäus and Sabine Rogge. Möhnesee: Bibliopolis, pp. 1-17.

Dawson, Helen. 2019. As Good as it Gets? "Optimal Marginality" in the Longue Durée of the Mediterranean Islands. Journal of Eastern Mediterranean Archaeology and Heritage Studies 7: 451-65. [CrossRef]

Depalmas, Anna. 2005. Luoghi di culto e santuari della Sardegna nuragica. Histria Antiqua 13: 39-48. 
Depalmas, Anna. 2014. Il paesaggio del sacro nella Sardegna nuragica. Architetture celebrative e spazi cerimoniali nei luoghi di culto e nei santuari. In Paesaggi cerimoniali. Ricerche e scavi, Atti dell'Undicesimo Incontro di Studi (Valentano, VT-Pitigliano, GR, 14-16 Settembre 2012). Edited by Nuccia Negroni Catacchio. Milano: Centro Studi di Preistoria e Archeologia, pp. 481-96.

Depalmas, Anna. 2017. I villaggi. In La Sardegna Nuragica. Storia e Monumenti. Edited by Alberto Moravetti, Paolo Melis, Lavinia Foddai and Elisabetta Alba. Corpora delle antichità della Sardegna. Firenze: Carlo Delfino, pp. 101-13.

Depalmas, Anna. 2018a. Water and Cults in Nuragic Sardinia. Wire's Water 5.5. Available online: https://wires.onlinelibrary.wiley. com/doi/10.1002/wat2.1293 (accessed on 17 December 2021).

Depalmas, Anna. 2018b. Il villaggio nuragico di Sant'Imbenia di Alghero. In Il tempo dei nuraghi. La Sardegna dal XVIII all'VIII sec. a.C.. Edited by Tatiana Cossu, Mauro Perra and Alessandro Usai. Nuoro: Ilisso, pp. 117-19.

Depalmas, Anna, and Rita T. Melis. 2010. The Nuragic People: Their Settlement, Economic Activities and Use of Land, Sardinia, Italy. In Landscapes and Societies. Selected Cases. Edited by Peter I. Martini and Ward Chesworth. Stuttgard: Springer, pp. 167-86.

Depalmas, Anna, Bulla Claudio, and Giovanna Fundoni. 2016. I santuari nuragici: Architettura, organizzazione e funzione degli spazi. In Santuari Mediterranei tra Oriente ed Occidente. Interazione e Contatti Culturali. Edited by Alfonsina Russo and Francesca Guarneri. Roma: Scienze e Lettere, pp. 341-49.

Depalmas, Anna, Bulla Claudio, and Giovanna Fundoni. 2017. Some Observations On Bronze Productions In Nuragic Sardinia Between Aegean Influences And Autonomous Creations. In Hesperos. The Aegean Seen from the West. Edited by Michael Fotiadis, Robert Laffineur, Yannos Lolos and Andreas Vlachopoulos. Aegaeum: Annales d'archéologie égéenne de l'Université de Liège et UT-PASP, vol. 41, pp. 81-92.

Depalmas, Anna, Bulla Claudio, Giovanna Fundoni, and Marco Zedda. 2021. Pasti rituali nei santuari "nuragici": Gli ambienti di servizio del santuario di Abini-Teti. In Preistoria del cibo. L'alimentazione nella preistoria e nella protostoria. Edited by Isabella Damiani, Alberto Cazzella and Valentina Copat. Studi di Preistoria e Protostoria, 6. Firenze: Istituto Italiano di Preistoria e Protostoria, pp. 789-98.

Elsner, Jas. 1995. Art and the Roman Viewer. The Transformation of Art from the Pagan World to Christianity. Cambridge: Cambridge University Press.

Georgiou, Artemis. 2012. Cyprus during the 'Crisis Years' revisited. In The Mediterranean Mirror: Cultural Contacts in the Mediterranean Sea between 1200 and 750 B.C., International Post-Doc and Young Researcher Conference, Heidelberg, Germany, 6-8 October 2012. Edited by Andrea Babbi, Friederike Bubenheimer-Erhart, Beatriz Marin-Aguilera and Simone Mühl. Römisch-Germanischen Zentralmuseums Tagungen 20. Mainz: Römisch-Germanischen Zentralmuseums, pp. 129-45.

Georgiou, Artemis, and Maria Iacovou. 2019. Cyprus. In A Companion to the Archaeology of Early Greece and the Mediterranean. Edited by Irene S. Lemos and Antonis Kotsonas. Oxford: Wiley and Blackwells Publications, pp. 1133-62.

Gordon, Jody M. 2018. Insularity and Identity in Roman Cyprus: Connectivity, Complexity, and Cultural Change. In Insularity and Identity in Roman Mediterranean. Edited by Anna Kouremenos. Oxford: Oxbow Books, pp. 4-39.

Gordon, Jody M. 2020. Introduction. In Mediterranean Archaeologies of Insularity in an Age of Globalization. Edited by Anna Kouremenos and Jody M. Gordon. Oxford: Oxbow Books, pp. 1-27.

Gradoli, Maria G., Paula Waiman-Barak, Teresa Bürge, Zachary C. Dunseth, Johannes H. Sterba, Fulvia Lo Schiavo, Mauro Perra, Serena Sabatini, and Peter M. Fischer. 2020. Cyprus and Sardinia in the Late Bronze Age: Nuragic Table Ware at Hala Sultan Tekke. Journal of Archaeological Science: Reports 33: 102479. [CrossRef]

Hadjikyriacou, Antonis. 2017. Envisioning Insularity in the Ottoman World. Princeton Papers. Interdisciplinary Journal of Middle Eastern Studies 18: vii-xix.

Iacovou, Maria. 2007. Advocating Cyprocentricism: An Indigenous Model for the Emergence of State Formation on Cyprus. In "Up to the Gates of Ekron". Essays on the Archaeology and History of the Eastern Mediterranean in Honor of Seymour Gitin. Edited by White Sidney Crawford and Amnon Ben-Tor. Jerusalem: The W.F. Albright Institute of Archaeological Research, pp. 461-75.

Iacovou, Maria. 2013. Historically Elusive and Internally Fragile Island Polities: The Intricacies of Cyprus's Political Geography in the Iron Age. Bulletin of the American Schools of Oriental Research 370: 15-47. [CrossRef]

Ialongo, Nicola. 2013. Sanctuaries and the Emergence of the Elites in Nuragic Sardinia during the Early Iron Age (ca. 950-720 BC): The Actualization of a 'Ritual Strategy'. Journal of Mediterranean Archaeology 26: 187-209. [CrossRef]

Ialongo, Nicola. 2017. N. Ialongo, Crisis and recovery: The Cost of Sustainable Development in Nuragic Sardinia. European Journal of Archaeology 21: 1-21.

Kardulias, Nick P. 2020. Afterwards. In Mediterranean Archaeologies of Insularity in an Age of Globalization. Edited by Anna Kouremenos and Jody M. Gordon. Oxford: Oxbow Books.

Kassianidou, Vasiliki. 2005. Was Copper Production under Divine Protection in Late Bronze Age Cyprus? Some Thoughts on an Old Question. In Cyprus: Religion and Society. From the Late Bronze Age to the End of the Archaic Period. Proceedings of an International Symposium on Cypriot Archaeology, Erlangen, Germany, 23-24 July 2004. Edited by Vassos Karageorghis, Hartmut Matthäus and Sabine Rogge. Möhnesee: Bibliopolis, pp. 127-41.

Kearns, Catherine. 2018. Cyprus in the Surging Sea: Spatial Imaginations of the Eastern Mediterranean. TAPA 148: 45-74. [CrossRef] Knapp, A. Bernard. 1986. Copper Production and Divine Protection: Archaeology, Ideology and Social Complexity on Bronze Age Cyprus. Studies in Mediterranean Archaeology-Pocket Books 42. Göteborg: Paul Åströms Förlag. 
Knapp, A. Bernard. 1996. The Bronze Age Economy of Cyprus: Ritual, Ideology and the Sacred Landscape. In The Development of the Cypriot Economy. From the Prehistoric Period to the Present Day. Edited by Vassos Karageorghis and Demetrios Michaelides. Nicosia: The A.G. Leventis Foundation/Bank of Cyprus, pp. 71-106.

Knapp, A. Bernard. 1999. Ideational and Industrial Landscape on Prehistoric Cyprus. In Archaeologies of Landscape: Contemporary Perspectives. Edited by Wendy Ashmore and A. Bernard Knapp. Oxford: Blackwell, pp. 229-52.

Knapp, A. Bernard. 2008. Prehistoric and Protohistoric Cyprus: Identity, Insularity, and Connectivity. Oxford: Oxford University Press

Knapp, A. Bernard, and Peter van Dommelen. 2010. Material Connections. Mobility, Materiality and Mediterranean Identities. In Material Connections in the Ancient Mediterranean. Mobility, Materiality and Identity. Edited by A. Bernard Knapp and Peter van Dommelen. London: Routledge, pp. 1-18.

Knapp, A. Bernard, Russell Anthony, and Peter Van Dommelen. 2021. Cyprus, Sardinia and Sicily: A Maritime Perspective on Interaction, Connectivity and Imagination in Mediterranean Prehistory. Cambridge Archaeological Journal, 1-19. [CrossRef]

Knodell, Alex R., Demetrios Athanasoulis, Žarko Tankosić, John F. Cherry, Thanasis K. Garonis, Evan I. Levine, Denitsa Nenova, and Hüseyin Ç. Öztürk. 2020. An Island Archaeology of Uninhabited Landscapes: Offshore Islets near Paros, Greece (the Small Cycladic Islands Project). The Journal of Island and Coastal Archaeology. [CrossRef]

Kopaka, Katerina, and Gerald Cadogan. 2012. Two Mediterranean Island Life Modes, Two Island Archaeologies. Crete and Cyprus, how Near how Far? In Parallel Lives: Ancient Island Societies in Crete and Cyprus. Edited by Gerald Cadogan, Maria Iacovou, Katerina Kopaka and James Whitley. British School at Athens Studies 20. London: British School at Athens, pp. 17-33.

Kourou, Nota. 2002. Aegean and Cypriot Wheelmade Terracotta Figures of the Early Iron Age. Continuity and Disjunction. In Die nahöstlichen Kulturen und Griechenland an der Wende vom 2. zum 1. Jahrtausend v. Chr. Kontinuität und Wandel von Strukturen und Mechanismen kultureller Interaktion. Kolloquium des Sonderforschungsbereiches 295 "Kulturelle und sprachliche Kontakte" der Johannes Gutenberg-Universität Mainz, 11-12 Dezember 1998. Edited by Eva Andrea Braun-Holzinger and Hartmut Matthäus. Mainz: Bibliopolis, pp. 11-38.

Lo Schiavo, Fulvia. 1992. Per uno studio sulle offerte nei santuari della Sardegna nuragica. Scienze dell'Antichità 1990: 3-4.

Lo Schiavo, Fulvia. 2018. Lingotti oxhide e oltre: Sintesi ed aggiornamenti nel Mediterraneo e in Sardegna. In Bronze Age Metallurgy on Mediterranean Islands: Volume in Honor of Robert Maddin and Vassos Karageorgis. Edited by Alessandra R. Giumlia-Mair and Fulvia Lo Schiavo. Monographies Instrumentum 56. Mergoil: Drémil-Lafage, pp. 15-55.

Madau, Marcello. 1997. Fenici e Indigeni a Nurdole di Orani. In Phoinikes B Shrdn. I Fenici in Sardegna. Edited by Paolo Bernardini, Rubens D'Oriano and Pier Giorgio Spanu. Oristano: La Memoria Storica, pp. 71-75.

Matta, Valentina. 2020. Sanctuaries in the Sardinian Bronze Age and Early Iron Age Landscape (1200-700 BC): Network Analysis and GIS Approach. Layers. Archeologia Territorio Contesti 5: 109-24.

Papantoniou, Giorgos. 2012a. Religion and Social Transformations in Cyprus. From the Cypriot Basileis to the Hellenistic Strategos. Mnemosyne Supplements 347. Leiden: Brill.

Papantoniou, Giorgos. 2012b. Cypriot Sanctuaries and Religion in the Early Iron Age: Views from Before and After. In Cyprus and the Aegean in the Early Iron Age. The Legacy of Nicolas Coldstream. Edited by Maria Iacovou. Nicosia: Bank of Cyprus Cultural Foundation, pp. 285-319.

Papantoniou, Giorgos. 2013a. The 'Cypriot Goddess' at the Transition from the Bronze Age to the Iron Age: A 'Cypro-Centric' Approach". In J.R.B. Stewart: An Archaeological Legacy. Edited by A. Bernard Knapp, Jennifer M. Webb and Andrew McCarthy. Studies in Mediterranean Archaeology 139. Uppsala: Astrom Editions, pp. 161-73.

Papantoniou, Giorgos. 2013b. Cyprus from Basileis to Strategos: A Landscape Approach. American Journal of Archaeology 117: 33-57. [CrossRef]

Papantoniou, Giorgos. 2016. Cypriot Ritual and Cult from the Bronze to the Iron Age: A longue-durée Approach. Journal of Greek Archaeology 1: 73-108.

Papantoniou, Giorgos. 2019. Unlocking Sacred Landscapes: The Applicability of a GIS Approach to the Territorial Formation of the Cypro-Archaic and Cypro-Classical Polities. In Unlocking Sacred Landscapes: Spatial Analysis of Ritual and Cult in the Mediterranean. Edited by Giorgos Papantoniou, Christine E. Morris and Athanasios K. Vionis. Studies in Mediterranean Archaeology 151. Nicosia: Astrom Editions, pp. 3-21.

Papantoniou, Giorgos, and Athanasios K. Vionis. 2018. The River as an Economic Asset: Settlement and Society in the Xeros Valley in Cyprus. Land 7: 157. [CrossRef]

Papantoniou, Giorgos, and Giorgos Bourogiannis. 2018. Sanctuaries as Central Places: Revisiting the Agia Irini Sanctuary in Iron Age Cyprus. Land 7: 139. [CrossRef]

Papantoniou, Giorgos, and Jennifer M. Webb. 2021. Funerary Ritual, Religious Ideology and Cult. In Cyprus. Crossroads of Civilizations. Edited by Luca Bombardieri and Elisa Panero. Turin: Musei Reali, pp. 179-85.

Papantoniou, Giorgos, and Niki Kyriakou. 2018. Sacred Landscapes and the Territoriality of Iron Age Cypriot Polities: The Applicability of GIS. American Journal of Archaeology 122: 541-77. [CrossRef]

Papantoniou, Giorgos, Christine E. Morris, and Athanasios K. Vionis. 2019. Spatial Analysis of Ritual and Cult: An Introduction. In Unlocking Sacred Landscapes: Spatial Analysis of Ritual and Cult in the Mediterreanean. Edited by Giorgos Papantoniou, Christine E. Morris and Athanasios K. Vionis. Studies in Mediterranean Archaeology 151. Nicosia: Astrom Editions, pp. ix-xviii. 
Roppa, Andrea. 2018. Connectivity, Trade and Punic Persistence: Insularity and Identity in Late Punic to Roman Republican Sardinia (3rd-1st century BC). In Insularity and Identity in the Roman Mediterranean. Edited by Anna Kouremenos. Oxford: Oxbow, pp. 144-64.

Rowlands, Michael. 1993. The Role of Memory in the Transmission of Culture. World Archaeology 25: 141-51. [CrossRef]

Russell, Anthony. 2020. Nuragic Networking? Assessing Globalization and Globalization in a Late Bronze Age Sardinian Context. In Mediterranean Archaeologies of Insularity in an Age of Globalization. Edited by Anna Kouremenos and Jody M. Gordon. Oxford: Oxbow Books, pp. 27-52.

Russell, Anthony, and A. Bernard Knapp. 2017. Sardinia and Cyprus: An Alternative View on Cypriotes in the Central Mediterranean. Papers of the British School at Rome 85: 1-35. [CrossRef]

Sabatini, Serena, and Fulvia Lo Schiavo. 2020. Late Bronze Age Metal Exploitation and Trade: Sardinia and Cyprus. Materials and Manufacturing Processes 35: 1501-18. [CrossRef]

Salis, Gianfranca. 2014. Schede. In La Sardegna Nuragica Storia e Materiali. Edited by Alberto Moravetti, Elisabetta Alba and Lavinia Foddai. Sassari: Carlo Delfino, pp. 282-88.

Salis, Gianfranca, and Marco Minoja. 2015. Un contributo al catalogo delle fibule rinvenute in Sardegna. Alcune considerazioni. Quaderni 26: 151-64.

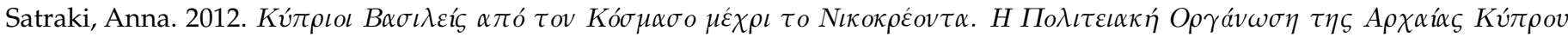

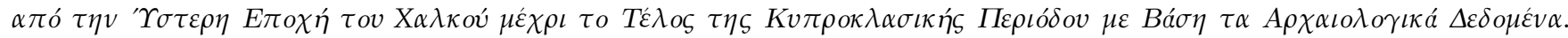

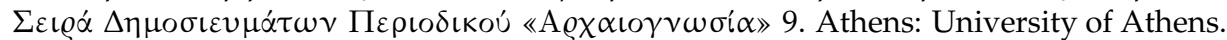

Schortman, Edward E., and Patricia A. Urban, eds. 1992. Resources, Power, and Interregional Interaction. London: Plenum Press.

Tore, Giovanni. 1983. I bronzi figurati fenicio-punici in Sardegna. In Atti del I Congresso Internazionale di Studi Fenici e Punici, Roma, Italy, 5-10 November 1979. Roma: CNR, pp. 449-61.

Usai, Alessandro. 2015. Paesaggi nuragici. In L'Isola delle Torri. Giovanni Lilliu e la Sardegna Nuragica. Edited by Marco Minoja, Gianfranca Salis and Luisanna Usai. Sassari: Carlo Delfino Editore, pp. 58-69.

van Dommelen, Peter. 1998. On Colonial Grounds. A Comparative Study of Colonialism and Rural Settlement in First Millennium BC West Central Sardinia. Archaeological Studies Leiden University 1. Leiden: University of Leiden.

van Dommelen, Peter. 2018. Trading Places? Sites of Mobility and Migration in the Iron Age West Mediterranean. In The Emporion in the Ancient Western Mediterranean. Trade and Colonial Encounters from the Archaic to the Hellenistic Period. Edited by Éric Gailledrat, Michael Dietler and Rosa Plana-Mallart. Montpellier: Presses Universitaires de la Méditerranée, pp. 219-29.

Vionis, Athanasios K., and Giorgos Papantoniou. 2019. Economic Landscapes and Transformed Mindscapes in Cyprus from Roman Times to the Early Middle Ages. In Change and Resilience: The Occupation of Mediterranean Islands in Late Antiquity. Edited by Miguel Ángel Cau Ontiveros and Catalina Mas Florit. Joukowsky Institute Publication 9. Oxford: Oxbow, pp. 257-84.

Vogiatzakis, Ioannis N., Maria Zomeni, and A. M. Mannion. 2017. Characterizing Islandscapes: Conceptual and Methodological Challenges Exemplified in the Mediterranean. Land 6: 14. [CrossRef]

Webb, Jennifer M. 1999. Ritual Architecture, Iconography and Practice in the Late Cypriot Bronze Age. Studies in Mediterranean ArchaeologyPocket Books 75. Jonsered: Paul Åströms Förlag.

Webb, Jennifer M. 2001. The Sanctuary of the Ingot God at Enkomi. A New Reading of its Construction, Use and Abandonment. In Contributions to the Archaeology and History of the Bronze and Iron Ages in the Eastern Mediterranean. Studies in Honour of P. Åström. Edited by Peter M. Fischer. Österreichisches Archäologisches Institut Sonderschriften 39. Vienna: Österreichisches Archäologisches Institut, pp. 69-82.

Webb, Jennifer M. 2014. Ritual as the Setting for Contentious Interaction: From Social Negotiation to Institutionalised Authority in Bronze Age Cyprus. In The Cambridge Prehistory of the Bronze and Iron Age Mediterranean. Edited by A. Bernard Knapp and Peter van Dommelen. Cambridge: Cambridge University Press, pp. 619-34.

Webb, Jennifer M. 2019a. Spatial and Social Discontinuities in Burial Practice and the Privatisation of Mortuary Space in Bronze Age Cyprus. Journal of Mediterranean Archaeology 31: 203-28. [CrossRef]

Webb, Jennifer M. 2019b. Socio-spatial discontinuities in burial ritual in prehistoric Bronze Age Cyprus. In Unlocking Sacred Landscapes: Spatial Analysis of Ritual and Cult in the Mediterranean. Edited by Giorgos Papantoniou, Christine E. Morris and Athanasios K. Vionis. Studies in Mediterranean Archaeology 151. Nicosia: Astrom Editions, pp. 171-88.

Webb, Jennifer M., and David Frankel. 2010. Social Strategies, Ritual and Cosmology in Early Bronze Age Cyprus: An Investigation of Burial Data from the North Coast. Levant 42: 185-209. [CrossRef]

Zeman-Wisniewska, Katarzyna. 2013. 'Goddesses with Upraised Arms' in Crete and Cyprus. A Comparative Study. Ph.D. dissertation, Trinity College Dublin, The University of Dublin, Dublin, Ireland. 